\title{
Effect of Glutamate Supplementation as a Feed Additive on Performance of Broiler Chickens
}

\author{
Vebera Maslami ${ }^{1}$, Mirnawati ${ }^{2}$, Jamsari ${ }^{3}$, Yuliaty Shafan Nur $^{2}$ and Yetti Marlida ${ }^{2 *}$ \\ ${ }^{1}$ Department of Agricultural Science, Faculty of Agriculture, Andalas University, 25163, Indonesia \\ ${ }^{2}$ Department of Animal Nutrition and Feed Technology, Faculty of Animal Science, Andalas University, 25163, Indonesia \\ ${ }^{3}$ Department of Crop Science, Faculty of Agriculture, University Andalas, 25163, Indonesia \\ "Corresponding author`s E-mail: yettimarlida@ansci.unand.ac.id ; ORCID: 0000-0001-5395-1297
}

Received: 12 Aug. 2019

Accepted: 17 Sept. 2019

\begin{abstract}
Feed additives are ingredients that are added to the ration as growth promoters and enhancement of the immune system. Glutamate is a feed additive that improves performance by improving the quality of the small intestine and enhancing the immune system. The purpose of this study was to know the effect of including glutamate as a feed additive in improving broiler performance. The material used in this study was broiler strain MB 202 from PT Charoen Phokphand Indonesia as many as 240 birds. The design used was a Completely Randomized Design (CRD) trial design, with six treatments and four replications, so that there were 24 cage plots as experimental units. Each experimental unit consisted of 10 chickens. The Glutamate doses in groups were, A ( $0.4 \%$ commercial glutamate; B ( $0 \%$ glutamate); C $(0.2 \%$ glutamate); $\mathrm{D}(0.4 \%$ glutamate); E (0.6\% glutamate); F (0.8\% glutamate). The results indicated that glutamate up to $0.8 \%$ had significant effects on feed intake body weight gain and feed conversion ratio (1.70\%), but it did not affect the percentage of carcass. It is concluded that including the $0.8 \%$ glutamate in broiler disets can improve broiler performance with 35 days of maintenance.
\end{abstract}

Key words: Feed additive, Glutamate, Growth promoters, Immune system, Performance

\section{INTRODUCTION}

The broiler is one of the meat-producing livestock that is quite potent in meeting the people's needs for animal protein needs. This is because broiler meat is relatively cheap and easy to obtain compared to other animal proteins. According to Ensminger et al. (2004) broilers have a fast and efficient growth in converting feed into meat. In addition, broilers also have weaknesses which tend to be susceptible to disease attacks which results in a decrease in broiler performance.

Supplementation of additional feed is one solution to prevent disease attacks by increasing immunity and growth promoters. According to Madhupriya et al. (2018) Feed additives are ingredients and add to rations to improve animal immunity and performance. Antibiotic Growth Promoter (AGP) is an antibiotic feed additive added to broiler feed. However, the use of AGP in broiler feed is prohibited because residues in broiler meat are harmful to public health. Residual hazards could reduce human resistance to consumption of certain types of antibiotics and other hazards (Ruegg, 2013; Singh et al., 2014). This had led to the enactment of the World Health Organization's regulation regarding the prohibition on the use of antibiotics in animal feed, hence the use of antibiotics as feed additives in broiler feed. So it is necessary to look for additional feed ingredients that are safer for livestock and the community. One safe and harmless feed additive is glutamate.

Glutamate is a feed additive that can improve growth promotes and enhances the broiler immune system. Glutamate functions was known as a constituent of proteins, a substrate in the synthesis of amino acids, as a precursor to several non-essential amino acids and helped the metabolism (Young and Ajami, 2000). According to Newholms et al. (2003); Reeds et al. (2000) glutamate could improve intestinal conditions by increasing intestinal villi length and increasing maintenance of 
intestinal integrity. In addition, according to $\mathrm{Li}$ et al. (2007) glutamate regulated Inductible Nitric Oxide Synthase (INOS) in certain tissues. The expression of INOS was considered as a fundamental mechanism in the protection of parasites, bacteria, fungi, malignant cells, intracellular protozoa and viruses in different animal species, including mammals and birds. The present study aimed to know the effect of giving glutamate as a feed additive in broilers.

\section{MATERIALS AND METHODS}

\section{Place of study}

This research was conducted on May-September 2018. Maintenance of broilers was conducted at the Poultry Division Field Laboratory, Faculty of Animal Husbandry, Andalas university, Indonesia.

\section{Materials}

A total of 240 one-day old male broiler chicks (MB 202 from) were purchased from PT Charoen Pokphand, Indonesia. The chickens were placed randomly into 24 cage plots (open cages), each measuring $1 \times 1 \mathrm{~m}^{2}$. Each plot was filled with 10 chickens, equipped with food and drinking water. This broiler cage was also equipped with 1 bulb (35 Watt). The ration was prepared by itself from feed ingredients consisting of corn, commercial feed (CP511 PT, Charoen Pokphand Indonesia), fish meal, soy flour, bran, palm oil and mineral premix. Nutrient content and feed composition was indicated in tables 1 and 2.

Table 1. Nutrient content of feed ingredients for broiler chickens

\begin{tabular}{lcccccc}
\hline \multirow{2}{*}{$\begin{array}{l}\text { Feed } \\
\text { ingredients }\end{array}$} & \multicolumn{5}{c}{$\begin{array}{c}\text { Nutritional content (\%) and } \\
\text { energy metabolism (Kkal/kg) }\end{array}$} \\
\cline { 2 - 7 } & $\begin{array}{c}\text { Crude } \\
\text { Protein }\end{array}$ & $\begin{array}{c}\text { Crude } \\
\text { Fiber }\end{array}$ & $\begin{array}{c}\text { Crude } \\
\text { Fat }\end{array}$ & Ca & P & ME \\
\hline Corn & 9.55 & 3.8 & 2.18 & 0.38 & 0.33 & 3300 \\
\hline Bran & 10.6 & 10.84 & 4.09 & 0.7 & 0.09 & 1592 \\
\hline Fish flour & 41 & 2.8 & 1.52 & 5.55 & 2.6 & 2580 \\
\hline $\begin{array}{l}\text { Commercial } \\
\text { Feed }\end{array}$ & 23 & 1.88 & 5.87 & 0.29 & 0.15 & 3200 \\
\hline $\begin{array}{l}\text { Soybean } \\
\text { Meal }\end{array}$ & 40.16 & 3.58 & 1.37 & 0.63 & 0.32 & 2240 \\
\hline Coconut oil & 0 & 0 & 100 & 0 & 0 & 8600 \\
\hline $\begin{array}{l}\text { Mineral } \\
\text { Premix }\end{array}$ & 0 & 0 & 0 & 5.38 & 1.14 & 0 \\
\hline
\end{tabular}

ME: Energy metabolism, Ca: Calcium, P: Phosphor; *Commercial Feed: CP511 PT, Charoen Pokphand Indonesia
Table 2. The composition of ration in broiler chickens

\begin{tabular}{|c|c|}
\hline Feed ingredients & $\begin{array}{l}\text { Percentage of ration (\%) } \\
\text { and nutrient content }(\%)\end{array}$ \\
\hline Corn & 40 \\
\hline Bran & 7 \\
\hline Fish flour & 17 \\
\hline Commercial Feed ${ }^{*}$ & 20 \\
\hline Soybean Meal & 14 \\
\hline Coconut oil & 1.5 \\
\hline Mineral Premix** & 0.5 \\
\hline Total & 100 \\
\hline Crude Protein & 21.75 \\
\hline Crude Fiber & 3.86 \\
\hline Crude Fat & 4.12 \\
\hline $\mathrm{Ca}$ & 1.50 \\
\hline $\mathrm{P}$ & 0.83 \\
\hline $\operatorname{ME}(\mathrm{Kcal} / \mathrm{kg})$ & 2952,64 \\
\hline \multicolumn{2}{|c|}{$\begin{array}{l}\text { Ca: Calcium, P: Phosphor, ME: Energy metabolism; *Commercial feed: } \\
\text { CP511 PT, Charoen Pokphand, Indonesia; **Mineral Premix: } \\
\text { Supplemented for kg of the diets: Vit. A, } 12000 \mathrm{IU} \text {; D3, } 2000 \mathrm{IU} \text {; E, } 20 \\
\mathrm{mg} \text { K3, } 3 \mathrm{mg} \text {; B2, } 7 \mathrm{mg} \text {; B3, } 12 \mathrm{mg} \text {; B5, } 3 \mathrm{mg} \text {; B12, } 0.03 \mathrm{mg} \text {; biotin, } 0.1 \\
\mathrm{mg} \text {; choline chloride, } 300 \mathrm{mg} \text {; Mn, } 130 \mathrm{mg} \text {; Fe, } 70 \mathrm{mg} \text {; Zn, } 60 \mathrm{mg} \text {; Cu, } 12 \\
\mathrm{mg} \text {; } 1 \text { mg; Se, } 0.2 \mathrm{mg} \text {, and adequate antioxidant. }\end{array}$} \\
\hline
\end{tabular}

\section{Method}

Making glutamate was done by fermentation with Lactobacillus plantarum. The nutritional composition of fermentation media used in this study was KH2PO4, $\mathrm{MgSO} 4$ _ $7 \mathrm{H} 2 \mathrm{O}, \mathrm{FeSO} 4$ _ $7 \mathrm{H} 2 \mathrm{O}, \mathrm{MnSO}_{\text {_ }} 4-5 \mathrm{H} 2 \mathrm{O}, 9 \%$ sugar cane, $5 \mu / \mathrm{L}$ biotin, $90 \%$ tofu water, $10 \%$ distilled water, water starter and starter $9 \%$. The duration of fermentation in this study was 36 hours at $36^{\circ} \mathrm{C}$. After fermentation the media were centrifuged for 20 minutes and $10,000 \mathrm{rpm}$ at a temperature of $-4^{\circ} \mathrm{C}$. After that, the supernatant was concentrated using an evaporation technique in an oven with a temperature of $40^{\circ} \mathrm{C}$ for 48 hours. The shrinking material was then calculated for the acid content using glutamate HPLC (Maslami et al., 2018).

\section{Maintenance of broilers}

Maintenance was carried out for five weeks. Feed and drinking water were available ad libitum. Glutamate treatment was given to chickens aged two weeks to six weeks. Glutamate was added to drinking water. The body weight was carried out at the beginning of the study and every following week, and also at the end of the study. Weighing the rest of the feed was done every weekend. Calculations were carried out for Feed Intake (FI), Body Weight Gain (BWG), Feed Conversion Ratio (FCR) and Carcass Percentage (CP). 


\section{Experiment and data analysis}

This study used a completely randomized design. Each treatment was repeated four times. Each treatment and each replication consisted of 10 birds. The observed variables were just performance traits. The variable performance included average feed intake, body weight gain, feed conversion ratio and carcass percentage. The data obtained were analyzed using analysis of variance (Analysis of Variance / ANOVA) and if there were differences between treatments were tested further using the DMRT (Duncan Multiple Range Test) tests at a level of 5\% (Steel and Torrie, 1991). The dose of glutamate in drinking water is A $(0.4 \%$ commercial glutamate), B
$(0.0 \%$ glutamate $), \quad \mathrm{C} \quad(0.2 \%$ glutamate $), \quad \mathrm{D} \quad(0.4 \%$ glutamate), $\mathrm{E}(0.6 \%$ glutamate $)$ and $\mathrm{F}(0.8 \%$ glutamate $)$.

\section{RESULTS AND DISCUSSION}

The results indicated that giving of glutamate had a significant effect $(\mathrm{P}<0.05)$ on feed intake, body weight gain and feed conversion ratio. While the giving of glutamate did not have a significant effect $(\mathrm{P}>0.05)$ on the percentage of the carcass. The average FI, BWG, FCR and CP by giving glutamate was indicated in table 3 .

Table 3. Effect of dietary inclusion of glutamate on broiler chicken performance for 35 days

\begin{tabular}{lcccc}
\hline Treatment & FI $(\mathbf{g})$ & BWG $(\mathbf{g})$ & FCR $(\%)$ & CP $(\%)$ \\
\hline A $(0.4 \%$ Commercial Glutamate $)$ & $4591.13^{\mathrm{a}} \pm 63.67$ & $2688.5^{\mathrm{a}} \pm 24.73$ & $1.71^{\mathrm{b}} \pm 0.03$ & $67.23 \pm 3.52$ \\
B $(0 \%$ Glutamate $)$ & $4429.05^{\mathrm{b}} \pm 77.25$ & $2391.50^{\mathrm{c}} \pm 28.25$ & $1.85^{\mathrm{a}} \pm 0.05$ & $68.76 \pm 1.80$ \\
C $(0.2 \%$ Glutamate $)$ & $4478.75^{\mathrm{ab}} \pm 84.25$ & $2450.63^{\mathrm{c}} \pm 54.96$ & $1.83^{\mathrm{a}} \pm 0.05$ & $73.21 \pm 3.62$ \\
D $(0.4 \%$ Glutamate $)$ & $4530.28^{\mathrm{ab}} \pm 76.08$ & $2573.60^{\mathrm{b}} \pm 63.79$ & $1.76^{\mathrm{b}} \pm 0.07$ & $70.70 \pm 3.44$ \\
E $(0.6 \%$ Glutamate $)$ & $4503.70^{\mathrm{ab}} \pm 103.94$ & $2634.15^{\mathrm{ab}} \pm 31.66$ & $1.71^{\mathrm{b}} \pm 0.04$ & $70.13 \pm 3.04$ \\
F $(0.8 \%$ Glutamate $)$ & $4588.68^{\mathrm{a}} \pm 26.24$ & $2693.95^{\mathrm{a}} \pm 74.06$ & $1.70^{\mathrm{b}} \pm 0.05$ & $70.47 \pm 4.39$ \\
\hline
\end{tabular}

FI: Feed intake, BWG: body weight gain, FCR: feed conversion ratio, CP: Carcass percentage.

\section{Feed intake}

It can be seen that group B was not significantly different $(\mathrm{P}>0.05)$ in the treatment of $\mathrm{C}, \mathrm{D}$ and $\mathrm{E}$ (Table 3). Judging from the average value there was a tendency to increase feed consumption with an increase in the dose of glutamic acid which can be the same as the consumption of ration by providing commercial glutamate. Increased consumption of rations with the addition of glutamate caused by glutamate can improve the quality of the digestive tract which can increase the absorption of nutrients. According to Ebadiasl (2011) glutamate in small bowel function as the formation of intestinal mucous villi cells. Bartell and Batal (2007) reported that glutamate supplementation could improve intestinal development with an increase in the relative weight of the duodenum and jejunum. Improving the development of the small intestine can increase the capacity of the digestive tract to accommodate the volume of the feed so that, many different rations can be consumed by broilers. According to Ibrahim (2008), larger intestines could increase ration consumption because a larger volume of food can be accommodated, digested, and absorbed.

In addition, the increase in ration consumption in this study was due to a decrease in stress on broilers. Reducing stress by adding glutamate because it can synthesize amino acids which have a role in reducing stress levels.
According to Young and Ajami (2000) stated that glutamate is an amino acid builder protein which is a precursor for Gamma AminoButyric Acid (GABA). Glutamate will be converted into GABA if broilers were under stress. According to Wang et al. (2015) and Lener et al. (2017) GABA served to reduce stress so that it can maintain appetite and increase the efficiency of the use of body nutrients in livestock. Thus giving glutamate to broiler chickens can reduce stress by increasing feed consumption. Feed intake in this study was between 4478.75-4588.68 g lower than that obtained by Bezerra et al. (2015) which was $5303 \mathrm{~g}$ for 42 days of maintenance. Similar study was presented by Olubodun et al. (2015) that administrated $0.5 \%$ of glutamate to broilers and indicated consumption of $4083 \mathrm{~g}$ feed.

\section{Body weight gain}

The body weight gain was increased as an increasing dose of glutamate. Giving glutamate in the treatment of $\mathrm{F}$ can increase weight gain, but not significantly different $(\mathrm{P}>0.05)$ with treatment $\mathrm{E}$. Body weight gain was influenced by feed consumption, the higher the consumption of food, the more weight gain was generated. According to Fadilah (2005) feed consumption had a positive effect on weight gain. Increased glutamate dose in this treatment caused by an increase in absorption of 
nutrients in small intestine. This is supported by the opinion of Shakeri et al. (2014) stated that administration of glutamate in broiler feed could improve small bowel development, intestinal villi length and nutrient absorption. Glutamate in the small intestine plays a role in the mechanism of intestinal mucosal defense by increasing the mucosal layer (Akiba et al., 2009). Increasing the inner surface and surface area of the small intestine will increase the digestion and absorption of feed extracts by the small intestine (Yao et al., 2006).

Giving glutamate can increase broiler weight because glutamate is a precursor for non-essential amino acids, so it will meet the needs of several other essential amino acids. According to Blachier et al. (2009) stated that glutamate is a precursor to other non-essential amino acids, such as arginine, glutamine, and proline. With the fulfillment of the need for non-essential amino acids will increase the growth of broilers. According to Ajinamoto (2007) and Maslami et al. (2018) administration of glutamate in broiler chicken feed could increase the growth of connective tissue so that, it can increase broiler body weight gain.

The highest weight gain in this study was found in treatment F (2646.45 g / bird) which could match treatment A with commercial glutamate ( $2638.35 \mathrm{~g} /$ bird). The body weight gain in broiler chickens of this study was higher than that reported by Olubodun et al. (2005) at 42 days of age (2375 g / bird). Increased body weight gain by adding glutamate to broilers diet was reported by Porto et al. (2015). Furthermore, according to Bezerra et al. (2015) the addition of $1.76 \%$ glutamate could match the increase in broiler body weight gain without a reduction in crude protein ration. Moreover, according to this study addition of $1.76 \%$ glutamate could increase body weight gain of broilers with a crude low protein ration.

\section{Feed conversion ratio}

The results indicated that treatment groups $(\mathrm{D}, \mathrm{E}$ and F) gave the same low FCR, even matching treatment A with commercial glutamate. FCR was low by giving glutamate along with increased feed intake and body weight gain. A low FCR indicates an increase in feed efficiency (Razak et al., 2016). According to Usman (2009) and Zuidhof et al. (2014) the values of FCR were influenced by the amount of feed intake and body weight gain. Another factor is the increase in feed conversion with increasing doses because glutamate can improve the nutritional quality of feed and the digestive system. It was reported by Andriyanto et al. (2015) the nutritional quality of feed could influence broiler feed conversion. Decreased
FCR caused by administration of glutamate could improve the quality of the digestive system by increasing intestinal length thereby increasing absorption of feed nutrients (Olubodun et al., 2015). Increasing absorption of feed nutrients causes an increase in body weight so that it will increase the efficiency of feed use.

The lowest FCR in this study was 1.70 lower than Shakeri et al. (2014) stated that the FCR in broilers with administration of glutamate was 1.95 Similar results were conveyed by Zulkifli et al. (2016) giving $1 \%$ glutamate to broiler could reduce FCR to 1.81 Furthermore, according to Olubodun et al. (2015) that added $0.5 \%$ of the mixture of glutamate and glutamine to broiler chicken diet and reported reduce in FCR (1.78.

\section{Carcass percentage}

The results of statistical analysis indicated that the administration of glutamate did not significantly affect $(\mathrm{P}>0.05)$ on the percentage of broiler carcass. The effect of giving glutamate on carcass percentage presented in table 3. The average carcass percentage of each treatment from treatment $\mathrm{A}$ to treatment $\mathrm{F}$ was $67.23,68.76,73.21,70.70$, 70.13 , and $70.47 \%$ respectively. The percentage of the carcass in this study was at the range of $67.23-73.21 \%$ which was supported by Resnawati (2004) who studied in dietary addition of glutamate in broiler chickens and stated the percentage of carcass between $68-71.8 \%$. Glutamate is a building block of proteins that can increase protein synthesis in muscle tissue. Formation of protein in muscle tissue will affect the percentage of carcasses. According to Reeds et al. (2000), glutamate is one of the building blocks of amino acids from proteins that make up the body's protein.

\section{CONCLUSION}

Addition of glutamate up to $0.8 \%$ could improve the performance of broilers for 35 days of maintenance. However, administration of glutamate did not affect the percentage of the carcass. Further researches should to be conduct to indicate the ideal glutamate dose in broilers diet.

\section{DECLARATIONS}

\section{Acknowledgments}

All authors are very grateful to the Minister of Research, Technology and Higher Education of the Republic of Indonesia for support and finance through PMDSU No: No: 1387 / E4. 2015 and support through the B-Class World Class Professor Program Scheme 123.57 / D2.3 / KP / 2018. 


\section{Author's contribution}

Vebera Maslami and Yetti Marlida conducted the research, prepared data and performed statistical analysis. Mirnawati, Jamsari and Yuliaty Shafan Nur wrote the article. All authors checked and confirmed the final form of article.

\section{Competing interests} interests.

The authors declare that they have no competing

\section{Consent to publish}

All authors gave their informed consent prior to their inclusion in the study.

\section{REFERENCES}

Ajinomoto AN (2007). Influence of glutamic acid on broiler carcass quality. Poultry Research Report 19. Available at: http://www.lysine.com/pdf/poultry/prr19.pdf.

Akiba Y, Watanabe C, Mizumori $\mathrm{M}$ and Kaunitz JD (2009). Luminal l-glutamate enhances duodenal mucosal defense mechanisms via multiple glutamate receptors in rats. American Journal of Physiology-Gastrointest Liver Physiology, 297: 781-791. DOI: https://10.1152/ajpgi.90605.2008

Andriyanto, Satyaningtijas AS, Yufiadri R, Wulandari R, Darwin VM and and Siburian SNA (2015). Performance and digestibility of broiler chicken feed fed with testosterone in multilevel doses. Journal Acta Veterinaria Indonesiana, 3 (1): 29-37.

Bartell S and Batal A (2007). The effect of supplemental glutamine on growth performance, development of the gastrointestinal tract, and humoral immune response of broilers. Poultry Science, 86:1940-1947. DOI: https://10.1093/ps/86.9.1940.

Bezerra RM, Costa GP, Givisiez PEN, Freitas ER, Goulart CC, Santos RA, Souza JG, Brandao PA, Lima MR, Melo ML, etal. (2016). Effect of L-glutamate acid supplementation on performance and nitrogen balance of broilers fed low protein diets. Journal of animal physiology and animal nutrition, 100: 590-600. DOI: https://10.1111/jpn.2405.

Blachier F, Boutry C, Bos C and Tome D (2009). Metabolism and functions of L-glutamate in the epithelial cells of the small and large intestines. Am J Clin Nutr, 90(3):814-821 DOI: https://10.3945/ajen.2009.27462S.

Ebadiasl G (2011). Effects of supplemental glutamine and glutamate on growth performance, gastrointestinal development, jejunum morphology and Clostridium perfringens count in caecum of broilers. Thesis. Available at: https://https://core.ac.uk/download/pdf/11987364.pdf

Ensminger ME, Scanes CG and Brant G (2004). Poultry Scince. 4th Edition. Pearson Prentice Hall, New.

Ibrahim S (2008). Hubungan ukuran-ukuran usus halus dengan berat badan broiler. Agripet, 8(2): 42- 46. DOI: https://10.17969/agripet.v8i2.615

Fadilah Y (2005). Panduan Mengelola Peternakan Ayam Broiler Komersial. Agromedia. Pustaka. Jakarta.
Lener MS, Niciu MJ, Ballard ED, Park M, Park LT, Nugent A and Zarate CA (2017). Glutamate and GABA systems in the pathophysiology of major depression and antidepressant response to ketamine. Biological Psychiatry, 81(10): 886-897. DOI: https://10.1016/j.biopsych.2016.05.005

Li P, Yin YL and Li D. 2007. Amino acids and immune function. British Journal of Nutrition 98: 237- 252. DOI: https://10.1017/S000711450769936X

Madhupriya V, Shamsudeen P, Raj Manohar G, Senthilkumar S, Soundarapandiyan V and Moorthy (2018). Phyto feed additives in poultry nutrition - a review, International Journal of Science, Environment and Technology, Available at: http://www.ijset.net/journal/2109.pdf

Maslami V, Marlida Y, Mirnawati, Jamsari and Nur YS (2018). Optimization of glutamate production from Lactobacillus plantarum originating from Minangkabau fermented food as a feed supplement for broiler. Pakistan Journal of Nutrition, 17(7): 336-343. DOI: https://10.2923/pjn.2018.336.343.

Maslami V, Marlida Y, Mirnawati, Jamsari, Nur YS, Adzitey F and Huda N (2018). A review on potential of glutamate producing lactic acid bacteria of west Sumatera's fermented food origin, As feed additive for broiler chicken. Journal of World's Poutry Research, 8(4):120126. PII: S2322455X1800017-8

Nampoothiri K, Madhavan and Ashok P (1996). Urease Activity in a Glutamate Producing Brevibacterium sp. Procrss Biochemistry, 31: 471-475. DOI: https://10.1016/S00329592(95)00090-9.

Olubodun JO, Zulkifli I, Farjam AS, Hair-Bejo M and Kasim A (2015). Glutamine and glutamic acid supplementation enhances performance of broiler chickens under the hot and humid tropical condition. Italian Journal of Animal Science, $14 \quad$ (3263): $\quad 25-29$. $\quad$ DOI: https://10.4081/ijas.2015.3263.

Porto ML, Givisiez PEN, Saraiva EP, Costa FGP, Moreira Filho ALB, Andrade MFS, Brandão PA and Guerra RR (2015). Glutamic Acid Improves Body Weight Gainand Intestinal Morphology of Broiler Chickens Submitted to Heat Stress. Brazilian Journal of Poultry Science, 17 (3): 355362. DOI: https://10.1590/1516-635x1703355-362.

Razak AD Kiramang K and Hidayat MN (2016). Increase in body weight, feed consumption and feed conversion of broilers fed with betel leaf flour (Piper Betle Linn) as feed additives, 3: 135-147. Availabe at: http://journal.uinalauddin.ac.id/index.php/jiip/article/view/3924

Reeds PJ, Burrin DG, Stoll B and Jahoor F (2000). Intestinal glutamate metabolism. Journal of Nutrition, 130(4): 97882. DOI: https://10.1093/jn/130.4.978S.

Resnawati H (2004). Bobot potongan karkas dan lemak abdomen ayam ras pedaging yang diberi ransum mengandung tepung cacing tanah. Available at: http://peternakan.litbang.deptan.go.id/user/pros 04-75.pdf. (Accessed: 22 September 2018).

Ruegg PL (2013). Antimicrobial residues and resistance: Understand-ing and managing drug usage on dairy rarms. University of Wisconsin, Departement of Dairy Science, Madison. 
Saputra WY, Mahfudz LD dan Suthama N (2013). Pemberian pakan single step down dengan penambahan asam sitrat sebagai acidifier terhadap performa pertumbuhan broiler. Animal Agriculture Journal, 2(3): 61-72. Available at: http://ejournal-s1.undip.ac.id/index.php/aaj

Shakeri M, Zulkifli I, Soleimani AF, Reilly ELO, Eckersall PD, Anna AA, kumara S and Abdullah FFJ (2014). Response to dietary supplementation of L-glutamine and Lglutamate in broiler chickens reared at different stocking densities under hot, humid tropical conditions. Poultry Science, 93:1-9. DOI: https://10.3382/ps.2014-03910.

Singh S, Sanjay S, Neelam T, Nitesh K dan Ritu P (2014). Antibiotic residues: a global challenge. An International Journal of Pharmaceutical Science. Pharma Science $\begin{array}{llll}\text { Monitor, } & 5 & \text { (3): } & 184-197 .\end{array}$ https://10.5455/vetworld.2008.375-377

Steel RGD and Torrie JH (1991). Prinsip dan Prosedur Statistika. Translated by Bambang Sumantri. PT. Gramedia Pustaka Utama. Jakarta

Usman (2009). Pertumbuhan ayam buras periode grower melalui pemberian tepung biji buah merah (Pandanus conoideus LAMK) sebagai pakan alternatif. Prosiding Seminar
Nasional Teknologi Peternakan dan Veteriner. Balai Pengkajian Teknologi Pertanian Papua.

Wang DM, Chacher, Liu HY, Wang JK, Lin J and Liu JX (2015). Effects of $\gamma$-aminobutyric acid on feed intake, growth performance and expression of related genes in growing lambs. Animal, 9(3): 445-448. DOI: https://10.1017/S1751731114002651.

Yao Y, Xiaoyan T, Haibo X, Jinchen K, Ming X and Xiaobing W (2006). Effect of choice feeding on performance gastrointestinal development and feed utilization of broilers. Asian-Australasian Journal of Animal Sciences, 19:91-96. DOI: https://10.5713/ajas.2006.91.

Young VR and Ajami AM (2000). Glutamate: an amino acid of particular distinction. Journal of Nutrition, 130: 892-900. DOI: https://10.1093/jn/130.4.892S.

Zuidhof MJ, Scheider BL, Carney VL, Korver DR and Robinson FE (2014). Growth, efficiency and yield of commercial broilers from 1957, 1978 and 2005. Poultry Science, 93(12): 2970-2982. DOI: https://10.3382/ps.2014-04291.

Zulkifli M, Shakeri M and Soleimani AF (2016). Dietary supplementation of L-glutamine and L-glutamate in broiler chicks subjected to delayed placement. Poultry Science, 1: 1-7. DOI: https://10.3382/ps/pew267. 